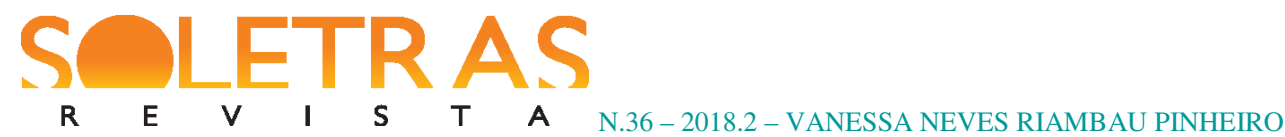

\title{
Entre fronteiras marítimas e corpóreas: apontamentos sobre os rumos da poesia moçambicana contemporânea
}

\author{
Vanessa Neves Riambau Pinheiro ${ }^{1}$
}

\begin{abstract}
Resumo: O propósito deste estudo é analisar a produção lírica moçambicana contemporânea a partir de alguns autores representativos cuja poética revela-se especialmente intimista. Inicialmente, retomaremos alguns elementos da formação da literatura dos países africanos de língua oficial portuguesa, em especial a de Moçambique, a fim de compreender a motivação épico-coletiva no momento de sua consolidação, nos períodos que antecederam e que sucederam a descolonização portuguesa. Após, nos deteremos em quatro poetas de Moçambique que foram recentemente publicados no Brasil, a saber: Ana Mafalda Leite, Sangare Okapi, Sónia Sultuane e Hirondina Joshua, tendo em conta aspectos que os diferenciam da poética de períodos anteriores, como a valorização do individual, do feminino e do erótico, além da revisitação de autores que os precederam e da retomada de temas como a Ilha de Moçambique e o Índico. Para embasar nosso estudo, recorreremos a Paz (2012), Mbembe (2014) e Noa (2002), entre outros.
\end{abstract}

Palavras-chave: Poesia moçambicana. Índico. Erótico.

Nas últimas décadas, o mundo ocidental tem visto o despontar das literaturas de nações emergentes, que foram geradas a partir do processo de descolonização engendrado, predominantemente, na segunda metade do século XX. Este processo ocorreu de forma simultânea à (re)construção identitária destes países, enquanto autônomos e livres do jugo colonial. Segundo o estudioso camaronês Achille Mbembe (2014), uma das imbricações da descolonização terá sido a destruição da forma Estado e das instituições herdadas da colonização. Esta destruição impeliu os nativos a forjarem uma nova história e nação, inventadas $^{2}$ e narradas literariamente. Evidentemente, foi preciso haver uma literatura que obedecesse aos moldes coloniais antes desta ruptura com o sistema. A respeito do tema, o pesquisador moçambicano Francisco Noa (2002) relata que a constituição da literatura nacional passou por várias etapas necessárias à sua consolidação atual:

Com a historicidade por si desenvolvida, passando do exotismo ao cosmopolitismo, do monovocalismo ao plurivocalismo, da afirmação categórica à expressão oblíqua, do estereótipo à valorização do Outro, das certezas às ambiguidades, do mito à utopia, a literatura colonial não só perturbou o cânone, como, por isso tudo, estabeleceu a ponte para a emergência de uma literatura nacional moçambicana (NOA, 2002, p. 402).

\footnotetext{
${ }^{1}$ Doutora em Letras (UFRGS). Professora Adjunta na graduação e na pós-graduação da Universidade Federal da Paraíba (UFPB), João Pessoa, PB, Brasil. Líder do Grupo de Pesquisa em Estudos de Literatura e Sociedade Contemporânea. Pesquisadora do CesA (Centro de Estudos sobre África, Ásia e América Latina).E-mail: vanessariambau@gmail.com.

${ }^{2}$ De acordo com a terminologia usada por Anderson (1998).
} 
Neste contexto, gostaríamos de destacar a literatura produzida nos PALOP $^{3}$; em particular, a produzida em Moçambique. Sabemos que se trata de uma literatura recente, que conta com pouco mais de cem anos de história. Não há obra significativa publicada antes do século XX, tanto na poesia quanto na prosa. Na poesia, considera-se Rui de Noronha (19091943) como o precursor do gênero. Outros poetas que obtiveram destaque nas décadas posteriores foram Glória de Sant'Anna, Orlando de Albuquerque, Orlando Mendes, Noémia de Sousa, Virgílio de Lemos, Rui Knopfli e José Craveirinha. Já na narrativa, foi significativa a publicação do livro intitulado $O$ livro da dor, do pioneiro da imprensa moçambicana João Albasini, que data de 1925. Outros autores relevantes do século XX são João Dias (Godido e outros contos, 1952) e, obviamente, Luís Bernardo Honwana, com o livro de contos Nós matámos o cão tinhoso (1964). Esta obra é considerada o marco da moderna prosa moçambicana. Todas estas obras refletiram, em maior ou menor grau, a necessidade de afirmação nacional e/ou crítica à colonização, condizentes com o momento sócio-histórico vivido pelo país africano. Obviamente, esta marca literária tornou-se mais intensa a partir da segunda metade do século XX, quando os partidos nacionais começaram a se organizar para, posteriormente, começarem a Guerra pela Libertação. $\mathrm{O}$ escritor, elemento icônico do sentimento nacionalista, era legitimado pela práxis revolucionária. De acordo com Edward Said (2011), o discurso literário pode transformar-se num veículo importante na definição da dependência cultural. Neste sentido, esta literatura foi pautada a partir de valores intrínsecos do que veio a tornar-se sua moçambicanidade.

A necessidade de autonomia através da literatura, como substrato ideológico para a formação do Estado-Nação, não é característica apenas de Moçambique. O ensaísta camaronês Achille Mbembe (2010), ao analisar a constituição dos nacionalismos nos países africanos, afirma que novos imaginários foram criados no período pós-colonial. Destes, duas tendências merecem destaque: a primeira, que se pauta no princípio da diferença e do reconhecimento de identidades particulares - o que contribui para a falácia da homogeneização cultural e da exclusão de representações autóctones periféricas -, e a segunda, que reconhece as singularidades, mas considera apenas a noção de comunidade e não a de indivíduo. Dessa maneira, podemos observar na representação literária destes países que emergiram do contexto colonial uma temática, de certa forma, obsessiva e restritiva,

\footnotetext{
${ }^{3}$ Países Africanos de Língua Oficial Portuguesa. 
pautada ou na perpetuação do nativismo ou na necessidade de legitimar-se literariamente enquanto destino coletivo e épico da nação. Ou seja, para que acontecesse a consolidação de sua autonomia literária foi preciso, antes, que houvesse a reprodução do estereótipo colonialista. Ainda de acordo com Mbembe (2010), o nativismo é, também, uma invenção colonial, que serviu para justificar o comportamento dos colonos. Este pensamento já havia sido mencionado por Francisco Noa (2002), que afirma que a literatura colonial é uma das criações mais significativas da colonização moderna. Neste sentido, um dos maiores desafios da literatura pós-europeia é exatamente reverter este poder epistêmico colonial. África, a “casa sem chaves”, como se refere Mbembe (2010), empreende, desde a descolonização, uma reorganização de espaços, sociedade, cultura e representações.

Como não poderia deixar de ser, o fim do período colonial engendrou novos temas e perspectivas literárias. "Agora, navegando mais ou menos livres, as novas nações independentes - sendo, na verdade, enxertias heterogéneas de fragmentos aparentemente incompatíveis e conglomerados de sociedade de longa duração - retomaram o seu curso, assumindo todos os riscos" (MBEMBE, 2014, p. 16).

$\mathrm{Na}$ atualidade, podemos constatar que a literatura moçambicana consolidou-se e que já encontra alguma projeção externa. O mercado editorial português e brasileiro são os principais consumidores da literatura africana escrita em português. Romancistas como Mia Couto e Paulina Chiziane são bons exemplos da literatura africana "de exportação"; entretanto, são poucos os que conseguem publicar fora de Moçambique. Ao analisarmos determinados fatores, poderemos compreender como se processa essa dinâmica de dependência exógena: a maioria das poucas livrarias concentra-se na capital Maputo, há poucas editoras, além de não ter adequada distribuição de livros. Além disso, não há iniciativas públicas no país que fomentem a leitura ou a formação do leitor. Não havendo força no mercado editorial interno nem adequada distribuição, não existem condições de se criar uma dinâmica editorial mobilizadora em Moçambique.

Gradualmente, entretanto, esta situação vem sendo modificada e outros autores estão começando a ser publicados por editoras brasileiras. Na poesia contemporânea, cerne do nosso estudo, podemos encontrar alguns poetas moçambicanos publicados no Brasil a partir do ano passado, como a luso-moçambicana Ana Mafalda Leite (Outras fronteiras: fragmentos de narrativas), Sangare Okapi (Mesmos barcos ou poemas de revisitação do corpo) e Sónia Sultuane (Roda das encarnações), publicados recentemente pela editora Kapulana; além da 
estreante autora Hirondina Joshua (Os ângulos da casa), publicada em Moçambique pela Fundação Fernando Leite Couto, e no Brasil pela Penalux Editora, ambos com prefácio de Mia Couto. Podemos perceber que, superado o momento nacionalista, os autores realizam incursões várias que dão conta de temáticas diversas. Bem antes desses autores citados, outros, como Eduardo White e Luís Carlos Patraquim, haviam iniciado este percurso de exploração temática na lírica. É como se este ampliar de perspectivas possibilitasse um desvelar mais íntimo, um explorar de geografias externas e internas simultâneas, que acaba por promover o arrefecimento da identidade coletiva em prol da particularização da escrita. Obviamente, Moçambique ainda é o cenário, por excelência, destes poemas, mas o país aparece diluído de fronteiras, podendo representar-se no Índico, nas cidades, nos barcos, nas casas, no próprio corpo físico do eu lírico ou até no ser amado. E nesta amálgama espacialafetiva, a heterogeneidade do país se revela a partir dos seus aspectos mais diversos. Temos a representação da Ilha de Moçambique, mítico lugar de heterogenias diversas, nos poemas de Sangare Okapi e de Ana Malfada Leite, por exemplo. Esta pluralidade identitária moçambicana, que encontra sua reverberação ideal na Ilha, caracteriza-se pela presença de indianos, paquistaneses, chineses... São, em geral, descendentes de imigrantes que se fixaram em Moçambique entre o final do século XIX e o início do século XX.

Num país plural como Moçambique, a Ilha e a representação do Índico configuram-se como espaços metonímicos por excelência, onde essa diversidade pode ser observada. A Ilha de Moçambique já foi cenário de muitas obras literárias e documentais moçambicanas. Destacamos aqui a publicação de A Ilha de Moçambique pela voz dos poetas (1992), organizado por Nelson Saúte e Latónio Sopa; A ilha de Próspero (1971), de Rui Knopfli; Monção (1980), de Luís Carlos Patraquim; e Amar sobre o Índico (1984), de Eduardo White, além de poetas anteriores que cantaram a Ilha, como Alberto de Lacerda, Glória de Sant'Anna, Orlando Mendes e Virgílio de Lemos. "Região geográfica de eleição na escrita dos poetas, a Ilha de Moçambique é caracterizada como lugar de encruzilhada de distintos valores estéticos e de esplendor pelos diversos registos culturais, orientais, africanos e europeus, lugar de uma memória múltipla e entrançada..." (LEITE, 2008, p. 256-257). Lugar de hábitos culturais diversos, sede de um sistema matriarcal, a Ilha configura-se como um espaço místico por excelência, não raro exótico aos próprios habitantes do Sul do país. Cabe lembrar que, ainda que este território insular já tenha sido cantado por poetas vários, o cenário 
predominante na literatura produzida em Moçambique ainda é o Sul, onde se concentra a região mais próspera do país, bem como a capital Maputo.

Ana Mafalda Leite, a veterana dos poetas recém-publicados no Brasil, conta com noves títulos de poesia editados em Moçambique e em Portugal. No entanto, é significativo que seu primeiro livro publicado no Brasil seja este último, Outras fronteiras: fragmentos de narrativas. Afinal, aqui a autora realiza um percurso geográfico e literário para dar conta do seu hibridismo identitário. Nascida em Lisboa, mas criada em Moçambique até a juventude, Ana Mafalda reflete, em seus poemas, este contexto multifacetado do qual faz parte. E, no desvelar dos seus poemas, temos acesso às perspectivas do eu lírico que se revela por vezes cambiante e até paradoxal, mas sem nunca incorrer na dicotomia. Afinal, assim como indica a nigeriana Amina Mama (2010), hoje em dia os africanos entendem a africanidade como algo múltiplo, fluido, histórica e institucionalmente de acordo com as diversas dimensões da diferença, constantemente contestado e redefinido em resultado dos processos e lutas sociais.

Assim como sugere Octávio Paz (2012) em sua conhecida obra $O$ arco e a lira, o poema é composto por visão e símbolo, e metaforicamente representaria um caracol onde pudesse ressoar a música do mundo. A referida "música do mundo", a que se refere o autor, encontra-se no livro Outras fronteiras: fragmentos de narrativas. Na obra, estão presentes visões do paraíso, do limbo, do exílio, salvação e degredo, numa alegoria lírico-amorosa. Ao nos depararmos com a lírica de Ana Mafalda Leite, adentramos num universo de emoções palpáveis, desenhadas a partir de representações de imagologias diversas. Nos seus poemas, entramos em contato com sinestesias múltiplas, envoltas em difusas imagens de miragem e sonho, natureza e paisagens, numa perspectiva ora amorosa "ao deter-me devagar sobre tua imagem/como quem junta sóis ao amanhecer" (LEITE, 2017, p. 12), ora saudosa "Há nesse lugar do coração uma paisagem antiga/ sempre presente" (LEITE, 2017, p. 11), num representar de vozes ancestrais de desbravamento que dão conta de um autodesvendar-se "a que destinos ele pensava chegar?" (LEITE, 2017, p. 39).

Para desvendar este universo, que é o Índico e também Moçambique e Marrakesh, mesclado com paisagens brumosas de sonhos e enredos amorosos, há a evocação de cores "no princípio fomos azuis?”, “verdes-azuis-laranjas", travessias marítimas de "sossegos imperturbáveis de oceanos índicos" (LEITE, 2017, p. 55), numa mescla de "maré baixa, maré cheia e maresia" (2017, p. 56), sabores "sabor morno, gostosos, meloso, escorregoso" (LEITE, 2017, p. 67) e experiências sensoriais que singularizam este eu lírico, profundamente 
consciente do erotismo presente em sua feminilidade: "coxas arredondadas como do bule" (LEITE, 2017, p. 67).

Mais do que nos outros momentos da obra, nesta primeira parte, "Como se a manhã do tempo despertasse", o eu lírico é todo de descobertas, de transgressão de fronteiras íntimas e geográficas. Portugal também aparece nesta fronteira afetiva, através dos famosos versos de Camões, "amor é fogo que arde/ arde sem se ver" (LEITE, 2017, p. 18). Na hibridez identitária que constitui o eu lírico, impossível seria ignorar sua pertença lusitana. As fronteiras a serem rompidas dão conta também do gênero literário: a prosa é subvertida à poesia, os limiares são fronteiriços.

Neste desnudar paisagístico-amoroso, o eu lírico também aparece desvelado pelos olhos do amado: "Pareces uma paisagem com uma janela dentro, contas" (LEITE, 2017, p. 10); "respiro-te, ana, como se respiram as manhãs" (LEITE, 2017, p. 12).

A segunda parte é constituída pelos poemas de Moatize, "onde tudo começa" (LEITE, 2017, p. 22), nos quais se vivenciam afetos memorialistas de infância, amor, Moçambique, onde o eu lírico "mistura tudo nesta infância sem trégua" (LEITE, 2017, p. 24). E que, assim como a bola de tênis, é jogada de um lado a outro, na transfiguração de suas paisagens particulares. Ninguém volta duas vezes ao mesmo rio, diria Heráclito. E quando o rio são dois oceanos inteiros, Índico e Atlântico a movimentar correntezas íntimas? Para este eu-lírico, os caminhos estão abertos porque a fronteira é apenas uma etapa do percurso, que contempla identidades várias. "Abriram-se os portais e aqueles com quem estive vão e vêm passam/atravessam a fronteira/ deste lado de cá sentada na esteira pergunto-me/ quando será a minha viagem" (LEITE, 2017, p. 22).

$\mathrm{Na}$ terceira parte, que dá título à obra, as fronteiras são diluídas pelo eu-lírico, que se pergunta "onde terá começado a fronteira do dia com a noite? A fronteira da água a terra? Do azul com o lilás? Porque tão dividido o mundo em dois?” (LEITE, 2017, p. 34).

Os viajantes do velho mundo tornam-se personagens a partir de seus relatos sobre cidades moçambicanas. Aqui, a multiplicidade cultural e étnica de Moçambique é retratada, a partir da presença de portugueses, indianos, goeses e africanos, "entre oriente e ocidente" (LEITE, 2017, p. 49) em "insondáveis viagens" (LEITE, 2017, p. 49) e numa evocação às tradições.

$\mathrm{Na}$ quarta parte, o Índico aparece como cenário e personagem deste desfecho líriconarrativo, numa evocação paisagística-amorosa cujo amado é, simultaneamente, 
pertencimento - "entrelaçando-me mágica e inevitavelmente em ti" (LEITE, 2017, p. 63) e evasão, “chegava às areias e mal chegava logo partia.”(LEITE, 2017, p. 56), o que coloca em evidência uma perspectiva de expansão amorosa e geográfica: "em Marrakesh diz-me o meu amor/ que o céu sem nuvens anuncia o deserto...” (LEITE, 2017, p. 54).

E nos labirintos dessa tessitura poético-narrativa, o eu-lírico reifica sua fusão memorialista mítico-sensorial de cores, sabores e paisagens, como se desta amálgama se formasse seu mosaico amoroso. "Talvez alguém tenha ouvido tua voz caminhando rente ao deserto/ e rente ao mar Índico/ do outro lado do tempo, num outro mar e num outro continente/ Aqui no deserto a geografia do amor é um estranho desenho" (LEITE, 2017, p. 73). Ao final deste percurso exploratório para dentro e fora de si, o cenário amoroso não nos foi guiado por Beatriz de Virgílio ou qualquer Odisseu retornado de outros mundos. O próprio oceano, transgressor natural de fronteiras artificias, configura-se na concretização do lugar idílico. "Chegamos assim/ muito enamorados/ à entrada dos azuis intensos do paraíso" (LEITE, 2017, p. 65).

Outro poeta que revisita o Índico na contemporaneidade é o moçambicano Sangare Okapi, com a obra Mesmos barcos ou poemas de revisitação do corpo (2017). A obra, publicada originalmente em Maputo em 2007 pela Associação dos Escritores Moçambicanos, ganhou recentemente sua primeira edição brasileira. Além desta, o escritor possui mais três obras de poesia publicadas em Moçambique.

O livro se organiza em três partes. Em todas, a presença dos poetas predecessores é invocada, numa exortação por vezes aparentemente aleatória e, por outras, quase sagrada, como se a ancestralidade legitimasse o seu próprio fazer poético que, afinal, reinventa-se através de sua poesia. A primeira epígrafe do livro já é bastante reveladora: "O primeiro passo nas ilhas é definitivo e irrevogável, marca-nos para o resto da vida o corpo em viagem" (Maria Orrico). No poema, a autora faz referência a outras ilhas (Açores), mas a ilação que se estabelece é também de míticos afluentes, que desaguam interna e externamente. Os primeiros poemas dão conta do universo marinho da Ilha, a partir de uma transfiguração eróticoamorosa em que a mulher desejada é personificada. "Amêijoa minha nocturna/tua é a cápsula aberta..." (OKAPI, 2017, p. 21). Esta(s) mulher(es), imprevisível como as correntes marítimas, vai, tal como esfinge, deixando-se revelar . "É como se outras portas de ti abrisse." (OKAPI, 2017, p. 24), na medida em que o eu lírico, impregnado do ambiente ilhéu, deixa-se ficar "bêbado de sal e sol. Absorto, como uma vela amarrada ao vento" (OKAPI, 2017, p. 26), 
à mercê do corpo-porto feminino, "cintura abaixo desaguar" (OKAPI, 2017, p. 31), porto "Com o mar/chegam os barcos/perto;/ com eles, teu corpo,/ porto/ para todos os partos." (OKAPI, 2017, p. 31) - e mar errante ao mesmo tempo. "O teu corpo é mar,/se amar/ para mim é errar" (OKAPI, 2017, p. 38).

Mas nem só de desejos e de sal está composta esta poesia; a referência à cultura multifacetada no Norte de Moçambique também se revela nos versos, ao mesmo tempo em que o poeta empresta seu próprio corpo para dar solidez ao orientalismo da região, como no poema "Insular": "Transporto outro poema/para o oriente do corpo" (OKAPI, 2017, p. 30). Consciente das múltiplas influências herdadas no país, o eu lírico realiza o percurso por estas referências, ciente de seu lugar entre elas - "Mesmo assim, te reergo a sal e passo todos os nomes, cujas/ naus mil deuses grego-orientais nossos costumes elevam..." (OKAPI, 2017, p. 25) -, ao mesmo tempo em que faz referência a danças e grupos étnicos locais, "reflexo primeiro no limiar de tudo o que nós, makondes,/ os deus em transe efusivamente pedem" (OKAPI, 2017, p. 48).

Ao definir-se, a exemplo de Ana Mafalda Leite, o poeta já não encontra mais suas fronteiras, diluídas nas águas do Índico, ciente de sua incompletude: "Eis o que sou: ilha/ ou corpo cercado/ de gente/ por todos os lados" (OKAPI, 2017, p. 32). Identificando-se como "ilha-corpo", o eu lírico não está livre das variações da maré, que o tornam ora prisioneiro "O mar/ é minha prisão" (OKAPI, 2017, p. 34), ora solitário "livrai-me desta solidão/ do mar,/ que me reduz à quilha" (OKAPI, 2017, p. 35) e nostálgico - "Oh! Aqui não há cais que aporte este caos de viver sempre/na nostalgia!" (OKAPI, 2017, p. 27).

Na segunda parte do livro, intitulada "Mesmos barcos", a poesia se aproxima à prosa como também o fizeram Ana Mafalda Leite, Luís Carlos Patraquim e Eduardo White. O próprio título, "Mesmos barcos", dá conta desta extratextualidade referencial. Ao aludir a barcos anteriores, o poeta busca o legado de poetas passados e situa-se dentro dessa temática mítico-semântica que é a Ilha de Moçambique, ao mesmo tempo em que transcende este passado que reverbera, mas não o limita. Afinal o barco, que é o mesmo, mas que também são outros, está em constante movimento. A epígrafe de Eugénio Lisboa dá conta desse elemento icônico, alusivo a insondáveis viagens, expectativas e desvelamentos vários. "Serão barcos? Serão marcos?/ Se calhar são só promessas.../E se fossem mesmo barcos?/ Vaguear e coisas dessas?" (OKAPI, 2017, p. 55). O barco também alegoriza a representação do corpo, materialidade possível nas águas profundas do Índico - índice de emoções, ora calmas, ora 
turbulentas. "Como um barco, sem porto, eriça a sensível vela do corpo e, frágil, o coração nos sirva de bússula" (OKAPI, 2017, p. 57).

Neste momento lírico-narrativo, outras paisagens afetivas se revelam, num transbordar propício ao movimento de um barco na maré cheia. Neste momento, o desejo, "irreprimível geografia do afecto" (OKAPI, 2017, p. 58), mistura-se às vagas ondas da paixão, numa consumação de exaltação amorosa:

Posso, agora, sem receio algum, vociferar no poema: amo-te! Amo-te as curvas, não sei que perigo ou mistério, a serena música das dunas no peito, romaria em alguma boca explodindo, ou então, a alga na bexiga se multiplicando. Olho a água, agora à nossa volta! A vertigem!?! Em ti, barco sem destino, nu me acoito inteiro e, se remar-te é engano, provável é agora rimarmo-nos (OKAPI, 2017, p. 59).

E nessa oscilação de marés íntimas, outros sentimentos são transbordados, como a angústia, à maneira lacaniana, oriunda do desejo, vontade irreprimível na qual se coadunam expectativas e receios de frustrações antecipadas: "há um pequeno país/ no meu país:/ chamase angústia" (OKAPI, 2017, p. 58). O desejo, como Schopenhauer (2012) conceitua, representa a expressão fenomenológica do ser humano; ao mesmo tempo força motriz da existência e razão de um sofrimento intrínseco à vida. Ainda de acordo com o filósofo, "O desejo, por sua natureza, é dor" (SCHOPENHAUER, 2012, p. 82). "Se em ti eu sofro todas as manhãs com o mesmo sol nos olhos e vagarosamente, percorro-te os panos do corpo, desarmo-te todas as armadilhas dos anzóis e afasto as algas da concha, porque só assim limpa e pura apeteces no poema" (OKAPI, 2017, p. 60).

A terceira parte do livro, intitulada "O barco encalhado", homenageia o oitocentista Campos Oliveira, primeiro poeta de Moçambique a versejar sobre a Ilha. O poema, de título homônimo, único na última parte, mostra as culturas sobrepostas que aportaram no decorrer dos séculos na Ilha de Moçambique, ensejando a aspiração de uma nova cultura hibridizada, à parte de criticar a pilhagem colonialista:

Resgatasse o Índico o que do oriente com o tempo soube sufragar.

Os barcos todos com as velas hirtas e as gentes.

Suas as pérolas mais os rubis. O aljôfar. Luzindo no ar.

Minha fracturada chávena árabe-persa na cal 
ou resplandecente a missanga cravada no ventre d'água,

qual sinal dos que de além mar chegaram

e partiram com baús fartos...

Fobia dos que ficamos. Mas herdeiros.

(OKAPI, 2017, p. 65)

Ao terminar a obra homenageando a poesia matriz de Campos Oliveira, Sangare Okapi encerra o percurso de revisitação de barcos e corpos poéticos. Ciclicamente, o poeta vai revelando influências várias de paisagens, culturas e mares. Nesta reconfiguração lírica, as emoções do eu lírico fundem-se com o Índico, misterioso e imprevisível. Corpos-barco que aportam em corpos-porto, embalados pelo contínuo movimento das marés que oscilam entre a angústia e o desejo, envoltos em uma mística hibridez paisagística-amorosa. Vai, portanto, ao encontro de Leite (2003, p. 137), quando esta afirma que

[...] o processo de mitificação literário da Ilha de Moçambique tem vindo a ser actualizado e amplificado, nos últimos anos, com maior insistência na obra de vários autores, concretizando percursos alternativos a uma poética militante, e de cariz ideológico, conferindo uma outra amplitude aos imaginários poéticos, e actualizando uma 'herança' e tradição literárias, muito antigas.

As paisagens íntimas também se tornaram tema de outras duas autoras moçambicanas publicadas recentemente no Brasil, Sónia Sultuane e Hirondina Joshua. Na obra delas, outros vieses continentais são contemplados. Roda das encarnações (2017), de Sónia Sultuane, o único dos seis livros da autora que ganhou edição brasileira, mimetiza vários aspectos concernentes à feminilidade, como a maternidade, a sexualidade, a erotização e o amor. $\mathrm{O}$ poema que dá título à obra dá conta desta miscelânea feminina:

Sou os olhos do Universo, a boca molhada dos oceanos, as mãos da terra, sou os dedos das florestas o amor que brota do nada, sou a liberdade das palavras quando gritam e rasgam o mundo, sou o que sinto sem pudor, sou a liberdade de mãos abertas, agarrando a vida por inteiro estou em milhares de desejos, em milhares de sentimentos sou o cosmos vivendo na harmonia na roda das encarnações . (SULTUANE, 2017, p. 13). 
Dedicado ao filho da autora, o poema dá conta da força-motriz feminina, inserida em um contexto de tempo cíclico e mitificado. Como o título do poema sugere, existe uma circularidade que antecipa a poeta e que irá se sobrepor a ela, composta pela representação de forças naturais "sou os olhos do Universo/a boca molhada dos oceanos/as mãos da terra,/ sou os dedos das florestas", bem como da configuração do sagrado feminino, a partir da sua onipresença mística, "estou em milhares de desejos, em milhares de sentimentos/ sou o cosmos". A sacralização do feminino como ser capaz gerador, princípio norteador da vida e do amor, aparece nos versos da poeta referida: "Em tempos gloriosos/visitarei todos os templos sagrados escondidos em mim" (SULTUANE, 2017, p. 42). O amor, como bem maior do ser humano, é vivenciado pelo eu lírico como um sentimento de origem matricial: "No meu coração vive todo o vocabulário/ que só eu entendo e comigo caminha/ um vocabulário todo ele sentimento, esperança e perdão" (SULTUANE, 2017, p. 14). Diferentemente da força viril masculina vista em Okapi, a mulher aqui aparece mais do que erotizada: como personificação da própria consumação afeto-carnal. Na volúpia deste ser sagrado que provém da vida, o amor tende ao espiritual, numa conjunção que sintetiza libido e expectativa amorosa, numa plenitude eminentemente feminina. "É hoje que me transformarei no arcoíris,/e darei à minha alegria a sedução de um canto de sereia/ e te cobrirei, ternamente, com a certeza do meu amor/ por inteiro." (SULTUANE, 2017, p. 74).

No misticismo, a um tempo carnal/libidinoso e espiritual/redentor buscado pelo eu lírico, o sagrado é inserido a partir das tentativas de purificação e sublimação de sentimentos passados- "o que permanece no nosso coração,/ é o que alma não esquece/ a sementeira é nossa" (SULTUANE, 20117, p. 1) - como se o tempo, de natureza cíclico, pudesse ser renovado a partir de sucessivas "rodas de encarnações", numa peregrinação místico-sensorial de alguém que busca liberdade para criar, ser e sonhar. "Quando faltarem asas/ sopra nas tuas mãos as palavras amarradas./ Voarão em liberdade poemas encantados" (SULTUANE, 20017, p. 22).

O poema "Ó Deus dos homens" (SULTUANE, 2017, p. 38) realça este vínculo do eu lírico com a transcendência, a partir do questionamento feito ao "Deus dos homens", que se mantém "sempre agrilhoado" aos desejos humanos. "na suave e inenarrável beleza que nos deste/de viver a liberdade/sem que nos seja permitido ser livres/ com o que sonhamos" (SULTUANE, 20017, p. 38). 
O mar, tema tão caro a Okapi e Leite, reaparece na lírica de Sultuane, mas não se restringe ao Índico. Nesta incursão íntimo-geográfica, o eu lírico relata a transcendência dos limites do corpo, numa experiência mítico-sensorial que almeja a reificação do humano com o divino a partir da simbiose com os elementos femininos da natureza:

Revivo sendo água de todos os mares, de todos os oceanos.

Cresço na liberdade das flores imitando o canto das aves.

Corro na areia quente dos desertos buscando o tesouro da vida.

Aprendo a ser humana com o calor que recebo do sol

e aprendo a guiar-me pelo misterioso e intenso brilho da lua,

que me faz iluminada e faz a minha alma transparente.

Ah, e aprendo a amar pelo sopro abençoado que Deus me lançou

no momento em que aprendia

os primeiros passos da vida.

(SULTUANE, 20017, p. 43).

Convém observar que o sagrado feminino, no qual o eu lírico insere seus poemas, não é feito dos mesmos elementos do cristianismo. Apesar de Deus ter sido invocado em vários poemas, o panteísmo predomina nos versos, que tem laivos pagãos. "parecia-me ouvir os suspiros do Universo/ contando-me todos os segredos/dos deuses da minha imaginação.” (SULTUANE, 2017, p. 39). Dessa forma, esta obra insere a mulher dentro do imaginário mítico-sacro-religioso, no qual a circularidade do tempo, tal qual uma "roda das encarnações", daria conta de alcançar a evolução da alma a partir da sublimação da dor e da evocação de sentimentos tais como "perdão", "amor", "esperança" e desejo de "liberdade". Assim, encerrando este ciclo temporal, o livro termina com três poemas que, à sua maneira, sintetizam a ambição da poeta: em "Desejo", percebe-se a feminilidade exposta em volúpia e afeto que, conforme já foi dito, apenas no feminino seria possível a perfeita consumação carnal-amorosa: "o meu desejo sorrindo,/ porque me quero feminina e toda tua." (SULTUANE, 2017, p. 78); em “Templo vivo", está expressa a simbiose corpo-natureza da qual falamos anteriormente: "Embarcar na asa da lua/ voltar para os braços do meu templo vivo" (SULTUANE, 2017, p. 79). Entretanto, ao final, nem a consciência do poder eróticoafetivo feminino nem sua reificação com os elementos da natureza teriam, por si só, a amplitude evolutiva que se espera de uma "roda das encarnações" se, ao final, continuássemos a viver como se a vida não fosse única: "Passamos uma vida inteira,/ a desperdiçar momentos mágicos/que seriam uma vida inteira/se verdadeiramente vividos" (SULTUANE, 2017, p. $80)$. 
O último livro a compor nosso corpus de pesquisa, Os ângulos da casa, da estreante Hirondina Joshua, apresenta nas epígrafes suas referências literárias, todas de autores pertencentes ao final do século XX e início do XXI. Temos aqui versos de Eduardo White, Herberto Hélder e Mia Couto, nos quais a representação icônica da casa é mencionada. Podemos observar que a obra divide-se em duas partes: a primeira, de nome homônimo ao título da obra, é composta por sete poemas; a segunda, sem nome referido, apresenta temáticas várias, que espelham o universo metonímico e surrealista da autora. Há, então, uma primeira parte "interna", onde as emoções, latentes, estão na "casa" - corpo poético do eu lírico -; e uma segunda parte, de sentimentos em expansão, onde elementos de paisagem externa são mencionados, como o pássaro, o fogo, a pedra.

Os poemas da primeira parte do livro dão conta dos diversos ambientes desta "casa" enquanto representação corpórea-material mimetizada; o primeiro refere-se à sala, que só adquire significado a partir da presença das pessoas. "Bem se vê: a verdadeira gravidade é a porta que canta com tons graves a aguda substância da existência. E quem está aí para ouvila? Quem está aí para senti-la?...” (JOSHUA, 2017, p. 17). O segundo poema, assim como o primeiro, refere-se a um ambiente da casa, mas o ressignifica a partir de um elemento específico. Agora, o espaço privilegiado é o quarto, cuja porta adquire dimensão de portal ao desconhecido: "Essa porta abrirá ao abismo, mas será um abismo do abissal, onde se vê o fundo desse quarto, antes de ser aquilo" (JOSHUA, 2017, p. 18). O terceiro poema fala sobre as escadas da casa, como "matéria orgânica" (JOSHUA, 2017, p. 19) cujos corpos do silêncio são deslocados. O quarto poema relata o ambiente emblemático do corredor, onde "a mão apressa-se para chegar entretanto não há destinos" (JOSHUA, 2017, p. 20) O próximo cenário a ser descrito é a cozinha, metonimicamente representada por seus móveis e utensílios: “As rugas da clandestinidade se voltam contra o tempo: o fogão fala, a água ruge" (JOSHUA, 2017, p. 21). A varanda, lugar onde "a testosterona agita os espaços compridos" (JOSHUA, 2017, p. 22) e o banheiro, onde o "vaso sanguinário se mistura com o vaso sanitário e forjam a estupidez da merda" (JOSHUA, 2017, p. 23). Todos estes ambientes coadunam-se ao corpo corpóreo-poético na manifestação de reações humanas diversas, como medo "a mão teme a cegueira da parede" (JOSHUA, 2017, p. 20), desencantos "dentro do coração, que é lareira gélida" (JOSHUA, 2017, p. 18) e memórias perdidas "O mal da liberdade: ver depressa e temer o esquecimento" (JOSHUA, 2017, p. 23). A casa, portanto, aparece como alegoria de emoções diversas represadas, que precisam sair pela "porta da rua" para ganharem dimensão e 
movimento. Não por acaso, no primeiro poema a seguir à alusão aos cantos da casa, o eu lírico exorta o leitor a acompanhá-lo nesta travessia de autodescoberta:

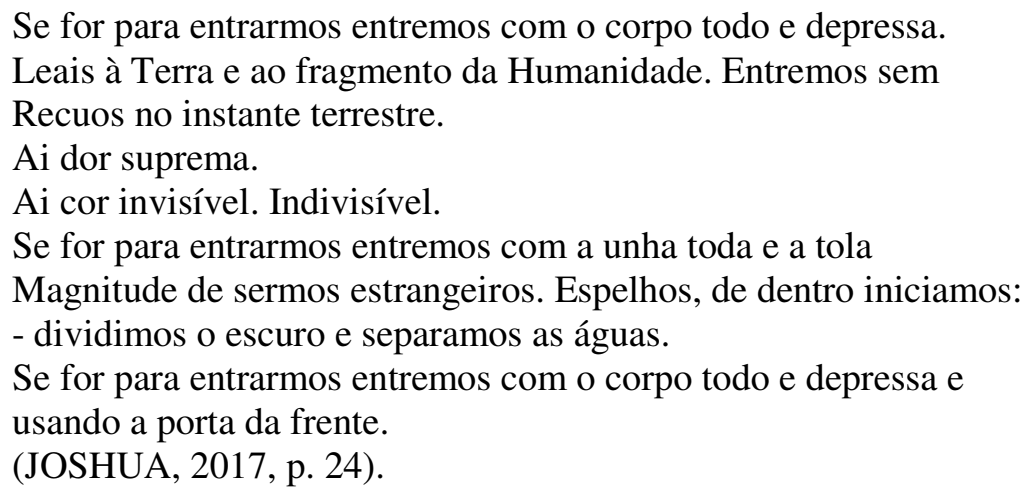

Os demais poemas que compõem este livro expandem a "casa" ao universo inteiro, num panteísmo que, ao mesmo tempo em que aproxima a autora de Sónia Sultuane, por sua ilação ao primevo e ao sagrado - "Morro e vivo inúmeras vezes" (JOSHUA, 2017, p. 28); "Nasci antes do tempo... Antes de mim" (JOSHUA, 2017, p. 34) -, também a particulariza pela escrita elaborada e sensacionista - à maneira pessoana - e pela vertente sinestésicasimbolista de seus versos, como podemos observar no poema abaixo, de nome "Prelúdio":

Como é que se escreve um olhar?

E um devaneio, sabes?

Para quê é preciso um coração? E uma alma o que é?

Diz-me se sabes a cor do vento.

A paixão com que o mar nos prende.

Diz-me, e por favor não poetizes nem filosofes.

(JOSHUA, 2017, p. 29)

A recusa da metafísica, por parte da autora, revela-se também em outros poemas, numa expectativa de que a compreensão da matéria baste à essência do transcendente espiritual e que este possa ser explicado por sua manifestação empírica. "Uma árvore traz sempre a febre do solo./ A inquietação da clássica epiderme da língua./Cava a minúscula boca dos sentidos:/Nasce onde a Vida pertence./Renasce na substância pura da matéria” (JOSHUA, 2017, p. 61).

Os laivos de erotismo, presentes em alguns poemas da autora, dão conta de um universo desprovido do feminino emotivo, tendendo mais à manifestação do desejo desromantizado. O sexo, enquanto "vocação carnal” (JOSHUA, 2017, p. 70), serve para 
"vingar a febre mundana" (JOSHUA, 2017, p. 71) e almeja a "supremacia cósmica" (JOSHUA, 2017, p. 76) que se vislumbra no fazer poético. "O poema acorda dentro um coração selvagem e a terra arde. / E tudo verte./ Em combustão nasce o mundo./ E a vida. / O suco" (JOSHUA, 2017, p. 76).

Desta forma, a escritura do poema aparece como labor sagrado que dá voz às palavras e as expande, ganhando dimensões míticas na perspectiva deste eu lírico, "O livro nasceu na veia./ Foi então que partiu pra dentro de outros mundos." (JOSHUA, 2017, p. 78), ao mesmo tempo em que restringe o saber oral do negro analfabeto. "Foi então que nasceu a selvagem Letra, nas mãos e nos dentes ferozes./ A escrita. A voz superlativa./ O canto cru./ Tudo lhe nascera rapidamente como a febre do universo./ - E ele não via” (JOSHUA, 2017, p. 78). E, nesta alquimia criativa, o fogo ganha proporções e densidades, transmutando-se à maneira de Eduardo White - citado na primeira epígrafe do livro - e revisitado pela jovem poeta:

Por exemplo, o fogo.

O fogo estabelece o seu trabalho,

a sua centígrada destreza para arder.

E não sei se notaste

que na digital matriz das suas febres

o fogo opõe-se,

insubmisso,

a morrer.

Arde como se definitivo

e quando assim sucede tende a crescer, busca aquela leveza das altas labaredas,

a implícita tontura das fagulhas.

O fogo arde como se quisesse fugir do chão,

das suas cavernas metalúrgicas,

ascende ao impulso dos foguetões,

à infância astral, à casa solar.

$\mathrm{O}$ fogo entristece, por vezes.

Chora inflamável na sua fatalidade terrestre

a estranha e lenhosa prisão

que o prende e embrutece.

Quer voar,

quer a sua ancestral condição de estrela

mas na corrida espacial com que o fogo queima,

na perpétua evasão,

a gula intestina-o

à sua pressa.

(WHITE, 1992, p. 19) 
Os poemas de Hirondina Joshua seguem a tendência de White, tanto na formulação lírica de alguns de seus versos "Por exemplo: a noite" (JOSHUA, 2017, p. 68); "Por exemplo:/ a música não anoitece" (JOSHUA, 2017, p. 40) quanto na recorrência temática: "Repara no que há dentro do fogo antes dele arder" (2017, p. 42); "No fogo, / Reside a pupila abstracta do poema " (JOSHUA, 2017, p. 51). Outros temas caros a Eduardo White, como a pedra - “A pedra/ Quando não move os lábios/ Anuncia a timidez” (JOSHUA, 2017, p. 47), a ave - "Aves são apenas asas na hora do voo" (JOHUA, 2017, p. 45) - e a casa - nos sete poemas que compõem a primeira parte do livro - também são evocados por Hirondina Joshua. Conforme relata Mia Couto (In WHITE, 1992, p. 9) em seu prefácio à edição portuguesa do livro de Eduardo White, “Tudo nesta escrita quer voar. A pedra, o fogo, a casa. Porque estes versos sugerem um ritual de iniciação ao belo, uma reaprendizagem do fascínio (...). Só o verso alcança a harmonia que supera os contrários - a condição de sermos terra e a aspiração do eterno etéreo". Assim como White, Hirondina busca a apreensão do voo no fazer poético. "[o poema] Não nasce, surge. Antecede a / Própria palavra, é o verbo do / Sangue das carnes mundanas e do / Insubmisso espírito humano" (JOSHUA, 2017, p. 56).

Nisto consiste a principal peculiaridade da poeta: na representação de um mundo insondável e irrestrito, no qual se coadunam elementos simbólicos concernentes à natureza, corpo e espírito. Revela-se uma autora de grande potencial imagético, que consegue o máximo efeito estético com o mínimo de palavras. "Repara como se traduz uma lágrima/ Diga-me se tem cor ou sexo a sua língua;/ a minúscula palavra que a habita./ Aves são apenas asas na hora do vôo" (JOSHUA, 2017, p. 47).

Ana Mafalda Leite, Sangare Okapi, Sónia Sultuane e Hirondina Joshua, poetas recémpublicados no Brasil, demonstram, através de sua lírica, a premência da subjetividade e de temas vários que buscam dar conta do híbrido moçambicano contemporâneo. Encontramos, por exemplo, o eu lírico em comunhão amorosa em Ana Mafalda Leite e em Sónia Sultuane; a ressignificação do sagrado nos três eus líricos femininos; a retomada do Índico como lugar mítico em Leite o Okapi; a erotização e o lirismo intimista em todos os poetas. Procuramos, em nosso estudo, revelar as múltiplas facetas deste fazer poético. Assim como os poetas referidos, há muitos outros talentos moçambicanos em devir que ainda não transpuseram as fronteiras até o Brasil - como Mbate Pedro, Andes Chivangue, Amosse Mucavele e outros. Sabemos que a literatura, enquanto representação icônica de um país, encontra plena reverberação em sua relação com o leitor. Neste sentido, nos alicerçamos na teoria de campo 
intelectual de Pierre Bordieu (1996), nomeadamente o conceito de capital simbólico, ou seja, tudo aquilo que confere valores culturais e nos permite identificar os agentes no espaço social. Não podemos, portanto, negar as implicações sociais repercutidas a partir da literatura, nem os por ela gerados.

Esperamos que, enquanto capital simbólico que representa a literatura, Moçambique alcance cada vez maior projeção e consolide-se, a exemplo de sua poesia, para além de suas fronteiras.

\section{Referências}

BOURDIEU, Pierre. Espaço social e espaço simbólico. In: Razões práticas. Sobre a teoria da ação. Campinas, SP: Papirus, 1996.

JOSHUA, Hirondina. Os ângulos da casa. Guaratinguetá, SP: Penalux, 2017.

LEITE, Ana Mafalda. Tópicos para uma História da literatura Moçambicana. In: RIBEIRO, Margarida Calafate; MENESES, Maria Paula. Moçambique das palavras escritas. Porto: Edições Afrontamento, 2008.

A reescrita de Caliban sobre a Ilha de Próspero: notas em torno da actualização de um mito de origem cultural. In: Lisboa: Colibri, 2003, p. 135-144. . Literaturas africanas e formulações pós-coloniais. Outras fronteiras: fragmentos de narrativas. São Paulo: Kapulana, 2017.

MAMA, Amina. Será ético estudar África? Considerações preliminares sobre pesquisa académica e liberdade. In: SANTOS, Boaventura de Souza; MENESES, Maria Paula. Epistemologias do Sul. 3. ed. Coimbra: Edições Almedina, 2010, pp.529-560.

MBEMBE, Achille. Crítica da razão negra. Lisboa: Antígona, 2014.

Sair da grande noite: Ensaio sobre a África descolonizada. Angola: Edições Mulemba; Portugal: Edições Pedago, 2010.

PAZ, Octávio. O arco e a lira. São Paulo: Fundo de Cultura Econômica Brasil, 2012.

SAID, Edward. Reflexões sobre o exílio e outros ensaios. São Paulo: Companhia das Letras, 2011.

SCHOPENHAUER, Arthur. Do mundo como vontade e representação. São Paulo: Saraiva, 2012.

SULTUANE, Sónia. Roda das encarnações. São Paulo: Kapulana, 2017. 
OKAPI, Sangare. Mesmos barcos ou poemas de revisitação do corpo. São Paulo: Kapulana, 2017.

WHITE, Eduardo. Poemas da ciência de voar e da engenharia de ser ave. Lisboa: Caminho, 1992.

\title{
Within marine and corporeal borders: notes on the directions of contemporary Mozambican poetry
}

\begin{abstract}
The purpose of this study is to analyze the contemporary Mozambican lyrical production from some representative authors whose poetics is especially intimate. Initially, we will retake some elements from the formation of the literature of African countries with Portuguese as official language, especially Mozambique, in order to comprehend the epiccollective motivation at the moment of its consolidation, in the periods that preceded and succeeded the Portuguese decolonization. Afterwards, we will focus on four poets from Mozambique who have recently been published in Brazil, namely: Ana Mafalda Leite, Sangare Okapi, Sónia Sultuane and Hirondina Joshua, taking into account aspects that differentiate them from the poetics of previous periods, such as the valuation of the self, the feminine and the erotic, as well as the revisiting of authors who preceded them and the resumption of themes such as the Island of Mozambique and the Indian Ocean. To support our study, we will refer to Paz (2012), Mbembe (2014) and Noa (2002), among others.
\end{abstract}

Keywords: Mozambican poetry. Indian Ocean. Feminine. Erotic.

Recebido em: 16 de abril de 2018.

Aceito em: 30 de julho de 2018. 